\title{
Influence of the European Trade Union Confederation on the development of trade unions in a transition country
}

\begin{abstract}
The role of the European Trade Union Confederation in creating mass participatory democracy is of great influence on trade union development in transition countries. Changes in society have given trade unions the specific role of transmitting the voice of workers into public spheres of life. How successful trade unions are, and the accuracy of the voice of workers that they carry, remains the key point of freedom of association. This article presents the influence of the European Trade Union Confederation on trade union development in a transition country, with special regard to the position in Bosnia and Herzegovina, and to the role of the ETUC in supporting social dialogue. In Bosnia and Herzegovina, the European Convention on Human Rights is directly applicable, in accordance with the BiH Constitution, and therefore the freedom of association guaranteed by the Convention is of utmost importance. The article concludes that the greater the independence of action that trade unions have in a transitional state, the better the level of social dialogue.
\end{abstract}

Keywords: European Trade Union Confederation, economic democracy, political and social democracy, transition, European Social Model, social dialogue, freedom of association, ECHR, European integration

Introduction

Trade unions, as a form of participation in industrial democracy by a specific and numerous part of the population, i.e. workers, are today far more sophisticated and developed than they were earlier in history. Unions are political organisations in which representative democracy is seen to be achieved through elections of union leaders (Colgan and Ledwith, 2002: 4), while participative democracy is represented through the participation of workers whose rights are the subject of their work.

The main function of trade unions, and the cause of their creation, is to achieve and protect the rights of workers. Those basic rights, as a set of ideas which provided the impulse to the founding of unions, were the right to working time; the right to paid leave; the right to wages; the eradication of child labour; the prohibition of discrimination; etc. Today, trade unions are led by similar ideas, except that workers are more aware of their rights in general and in particular areas, and are also both more precise and more sophisticated about them.

The role of trade unions in a state depends greatly on the attitude of the state towards the trade unions. If such a relationship is a liberal one, then the state has a partner for social bargaining and accepts trade unions as social partners in economic or political 
management (Jacobi et al, 1986). The functioning of trade unions reflects the level of democracy and shows how articulated are the interests of the members of trade unions in wider society (Harcourt and Wood, 2006: 35).

A state in transition, and in the process of regional integration, tries where it is not yet a member of the European Union, to follow the trends of developed countries, or specifically of the EU, and to incorporate them into its legal system as a means of getting close to modern democracies as quickly as possible. An important element of modern democracy is the undisturbed operation of trade unions, as organisations representing workers, in the sense of there being no obstacles in trade union relations with employer organisations and with the state; as well as of the development of industrial democracy.

Bosnia and Herzegovina, being a transitional state, constantly makes efforts to get closer to European principles in the process of the harmonisation of its laws. How successful it is depends not only upon the legally-adopted standards but upon the implementation of those standards in practice. Their implementation and the difference between the normative and the real world is dependent upon the constant changes in economic and social circumstances. Such changes often have a negative influence on the position of trade unions in European countries.

In the beginning, trade unions were seen as a class organisation, or as an expression of class solidarity (Colgan and Ledwith, 2002: 5). Then, alongside the processes of the uniting of Europe, they were seen as organisations of solidarity with migrant workers, as a result of labour's freedom of movement throughout Europe. Today, trade unions are more seen as expressions of international solidarity. On the one hand, the national aspect of trade unions has been preserved; but, on the other, an international element, via knowledge of international labour principles, and then through the joining of national trade unions to international trade union organisations, has also clearly been introduced. And that is how the European Trade Union Confederation was born.

\section{European Trade Union Confederation}

Having been founded in 1973, this organisation is today a pool for 85 trade union organisation members in 36 European countries and ten industrial federations. It is the only social partner representing workers at the European level. It aims to promote people's interests at European level by representing them in EU institutions. However, its significance is not only related to its widespread membership but to the constant promotion of the:

European Social Model and to work[ing] for the development of a united Europe of peace and stability where working people and their families can enjoy full human and civil rights and high living standards. The European Social Model embodies a society combining sustainable economic growth with ever-improving living and working standards, including full employment, social protection, equal opportunities, good quality jobs, social inclusion, and an open and democratic policy-making process that involves citizens fully in the decisions that affect them. ${ }^{I}$

1 www.etuc.org/r/12. 
The European Trade Union Confederation is an umbrella European institution that aims to gather together national trade unions. On the one hand, the freedom of action and diversity of national unions remains intact and respected; on the other, the ETUC takes responsibility for issuing directives and recommendations and for creating policy initiatives at European level. During 2012, the ETUC has adopted legal acts concerning lifelong learning, gender imbalance in the corporate bodies of EU, A Social Compact for Europe, the ETUC Action Programme on Gender Equality, etc.

\section{European social model and social dialogue}

The ETUC adopted a resolution at the meeting of its Executive Committee on 5-6 June 2012, ${ }^{2}$ named $A$ Social Compact for Europe. The main directives that come from this resolution are free collective bargaining and social dialogue as a part of the European Social Model, that must be guaranteed at both EU and national level. Each member state has been entrusted with taking measures in this regard. Furthermore, the autonomy of the social partners at national and European level must be respected, while workers' inclusion in collective agreements should be to the greatest possible extent. Those are the main streams of the European Social Model as presented by the ETUC.

In 1994, the European Commission adopted its white paper on Social Policy in the circumstances of the globalisation of trade and production; the huge impact of new technologies on work, society and individuals; the ageing of the population; the persistent high level of unemployment; and the need to react to those challenges, especially concerning labour law, health and safety, free movement and equal treatment between men and women. ${ }^{3}$ The white paper underlines the European Social Model of consensus based on reconciling economic effectiveness and social solidarity. The social partners have an important role through co-operation between state, employer and trade unions on social policy.

The European Social Model is these days underpinned by the Treaty on the Functioning of the European Union. This states that the aim of the Union is to eliminate inequalities and to promote equality between men and women; ${ }^{4}$ to promote a high level of employment; to provide a guarantee of adequate social protection; to fight against social exclusion; to ensure a high level of education, training and the protection of human health $;^{5}$ and to combat discrimination based on sex, racial or ethnic origin, religion or belief, disability, age or sexual orientation. ${ }^{6}$ The Treaty on the European Union is also based on the principles of the promotion of social justice and protection; the equality of men and women; and solidarity between the generations. ${ }^{7}$

2 ETUC (2012)A Social Compact for Europe, ETUC resolution, available at: http://www.etuc.org/ IMG/pdf/EN-A-social-compact-for-Europe.pdf.

3 Commission of the European Communities (1994) 'Preface' of European Social Policy: A Way Forward for the Union A White Paper, COM(94)333 final, Brussels, 27 July 1994.

4 Treaty on the Functioning of the European Union, Article 8.

5 ibid. Article 9.

6 ibid. Article 10.

7 Consolidated version of the Treaty on the European Union, Article 3, para. 3. 
One of the crucial characteristics of the European Social Model is social dialogue. ${ }^{8}$ To this extent, the important role is given to workers' representatives and the achievement of their rights through trade unions. Social dialogue is recognised by the ETUC as a factor for putting forward a social Europe. An uninterrupted social dialogue between large groups, i.e. associations of workers or trade unions on the one side and associations of employers on the other, in a favourable environment is the task of the state, a characteristic of modern democracies. The state is obliged to facilitate the active and free participation of workers in trade unions, as well as of employers in their respected associations. Workers must have freedom of association, as well as trade unions themselves, and their independent operation must not be impaired, provided that it is in line with their legal competencies and not contrary to public order.

Social dialogue as a positive feature of modern states, and a condition towards which they aim, is sometimes called 'social concertation' in which employers, workers' representatives and governments have developed a reflex for acting in a concerted, multifaceted manner to address all the major national economic and social policy issues on the basis of seeking to establish consensus (Trebilcock, 1994: 4).

The balanced participation of all three partners in social dialogue is necessary in order to create a favourable environment. In such tripartite co-operation, the state cannot be a passive partner. It needs to create a stable climate of civil and political rights that allow autonomous organisations to operate without fear of reprisal (Trebilcock, 1994: 30).

Is there social dialogue when some of the above characteristics are not in place? Should we search for a reply to a question of the existence of social dialogue in a situation in which civil and political rights are impaired or violated? Is successful social concertation possible if all the instruments are not coherent? If the sound of the violins is not heard in a philharmonic orchestra, then it is not philharmonic at all. Therefore, obstacles placed to the functioning of any of the social partners, among them most often trade unions, tend to act to jeopardise social dialogue.

\section{Violations of freedom of association}

Freedom of association relating to trade unions was stressed for the first time by the International Labour Organisation which, being a global organisation, conducts programmes with the aim of achieving better employment and programmes of social protection; carries out studies of the labour market and points to problems; and, by carrying out its global policies, aims to create changes in this sphere of society.

The ETUC carries out social action in the European sphere, while the Council of Europe has adopted the European Social Charter which, inter alia, stipulates that all workers and employers have the right to freedom of association in national and international organisations for the protection of their economic and social interests. ${ }^{9}$

However, the only European regional human rights document that provides, at the same time, judicial recourse on this issue at the European level is the European Con-

8 http://www.etuc.org/a/2771.

9 European Social Charter, Part 1, point 5. 
vention for the Protection of Human Rights and Fundamental Freedoms, Article 11 of which reads:

Everyone has the right to freedom of peaceful assembly and to freedom of association with others, including the right to form and to join trade unions for the protection of his interests.

Restrictions of this right are possible only in accordance with the law and if they are necessary in a democratic society in the interest of national and public safety, for the protection of health, morals, etc. ${ }^{10}$

The Lisbon Agreement created the possibility that the European Union should adopt the European Convention on Human Rights: the result would be that the European Union should become obliged by the Convention as well as a prospective respondent party in proceedings before the European Court of Human Rights.

The European Convention puts a double obligation on states. The first such obligation is a negative one, and obliges the state to abstain from interference in someone's rights. The second obligation is a positive one, and prohibits the state from being passive in those areas where it should react. Freedom of association regarding trade unions has, on several occasions, featured on the agenda of the European Court of Human Rights. Where the violation of freedom of association is established, then there is no appropriate social dialogue in such a state.

The case law of the European Court of Human Rights is especially useful for transitional countries that are newcomers to the terrain of modern social dialogue. Its judgments are obligatory for the states who are parties to a set of proceedings, but they also have a wider obligatory effect for all states that have ratified the Convention, ${ }^{11}$ which must render their legal systems in accordance with the Convention as a form of the prevention of any violation thereof.

For the purposes of this article, there are a few important judgments of the European Court that relate to violations of the right to form trade unions or which have arisen due to trade union membership.

In the case of Demir and Baykara $v$ Turkey, ${ }^{12}$ two citizens of Turkey complained that their national courts prevented them from organising a trade union, as well as from participating in collective bargaining and entering into collective agreements. One of them was the chair of the trade union Tüm Bel Sen, which was founded by public servants from various local communities on the grounds of the applicable Law on Public Service. The union entered into a collective agreement with one city council for a period of two years regarding the working conditions of that council's employees. However, the council did not respect the mentioned contract and the court protection was inadequate, the collective agreement being annulled.

10 European Convention for the Protection of Human Rights and Fundamental Freedoms, Article 11 , para. 2.

11 This has been done by 47 European states; only Belarus in Europe is not a member of the Council of Europe.

12 Judgment of the European Court of Human Rights in the case of Demir and Baykara v Turkey, 15 October 2008. 
The European Court pointed out that the right of public servants to become members of trade unions was recognised by all member states of the Council of Europe. Interference of the state, by way of the retrospective annulment of a collective agreement, was not 'necessary in democratic society' and led to a violation of Article 11 of the Convention. It is interesting that the European Court invoked universal and regional instruments that guarantee the right to form trade unions, such as the ILO Conventions.

At the same time, the rights of workers' representatives may be limited if public morals are at stake or if the rights of the other partner in bipartite dialogue, i.e. employers, are being offended.

In the case of Palomo Sánchez and others v Spain, the European Court found no violation of the right to form trade unions. Six citizens of Spain complained on the grounds that they had been dismissed from their jobs as a result of their membership of a trade union. They were employed as delivery workers and founded their union (Nueva alternativa asamblearia) in order to protect their interests and the interests of other workers from pressure by the company to give up their claims to salaried-worker status. In the trade union newsletter, they published a cartoon that, very offensively, depicted the company's human resources manager, humiliating him. After that, they were dismissed and the Labour Court in Barcelona rejected their claim, noting that the dismissals were reasonable.

The European Court invoked Recommendation No. 143 of the International Labour Organisation, according to which the management of the company should allow worker representatives to distribute newsletters, publications and other documents. However, the European Court pointed out that an attack on the respectability of individuals by using grossly insulting or offensive expressions in the professional environment is, on account of its disruptive effects, a particularly serious form of misconduct capable of justifying the measure of dismissal taken against the applicants. Thus, it concluded that the dismissal of the applicants was not a manifestly disproportionate or excessive sanction that had caused a violation of freedom of expression and freedom of association. ${ }^{13}$

On the other hand, in the case of Ceylan v Turkey, ${ }^{14}$ the applicant was President of the Trade Union of Petroleum Workers. In a weekly newspaper published in Istanbul, he wrote an article headed 'It is time for workers to speak out - tomorrow will be too late'. The result of that article was that he was sentenced, according to criminal law, for the crime of incitement to hatred and hostility, to one year and eight months imprisonment, and was also fined. He defended himself, stating that it is his duty as President to express his opinion on the democracy problem in south-east Turkey.

The European Court established that the conviction of the applicant was not necessary in a democratic society and was contrary to Article 10 of the Convention, i.e. the right to freedom of expression.

13 Judgment of the European Court of Human Rights in the case of Palomo Sanchez v Spain, 29 June 2011, paras. 76-78.

14 Judgment of the European Court of Human Rights in the case of Ceylan v Turkey, 16 June 1999. 


\section{The right to form trade unions in Bosnia and Herzegovina}

The Confederation of Trade Unions was founded as an umbrella organisation in Bosnia and Herzegovina in 2005, according to the constitutional division of powers for enacting and implementing labour legislation, the trade union situation in $\mathrm{BiH}$ and the requirements of the process of international integration. The Confederation of Trade Unions of Bosnia and Herzegovina, which is a full member of the International Confederation of Trade Unions and has observer status in the ETUC, was founded by the Independent Trade Union Association of $\mathrm{BiH}(\mathrm{SSSBiH}$, acting on the territory of the Federation of $\mathrm{BiH}$ ), the Trade Union Association of Republika Srpska (SSRS) and Trade Unions of the District of Brčko. SSSBiH gathers together 24 sector trade unions and eight cantonal offices; SSRS is an independent, non-party, non-political interest organisation founded in 1992 as an association of sector trade unions, which may associate with other trade union organisations in the strengthening of trade union cooperation, the development of international trade unions and the achievement of the freedoms and rights of trade union organisations and actions. ${ }^{15}$

Apart from there being numerous trade unions at all levels - general, sectoral, the entities, and at the level of Bosnia and Herzegovina - there are various public attitudes on the efficiency of trade unions in society and the extent of trade union pluralism. On the one hand, the right to organise trade unions is regulated at the level of the constitution and in labour laws, as well as through the ratified Conventions of the International Labour Organisation. However, on the other hand, normative quality standards are not reflected in the real world and in social opinion, bearing in mind both the individual right of membership and the collective rights of workers and trade unions to act in a trade union.

The key obstacle for the trade union being an equal partner, and not only one form of association, are the unfavourable economic and social circumstances and the high level of unemployment. These are presented in various reports on the problems faced by workers who participate in the work of trade unions as well as in overall actions taken by unions.

The International Confederation of Trade Unions, as a global organisation which co-operates closely with the ETUC and the International Labour Organisation, in its report on the violation of trade union rights around the world in 2011, stressed the key issues regarding trade union associations in Bosnia and Herzegovina (ITUC, 2012). Amongst other things, it stressed that the right to form trade unions was limited in practice; that there were pressures on workers preventing them from joining trade unions; and that the inefficiency of legal protection and the high rate of unemployment (amongst the highest in Europe), was such that workers often tolerate violations of their rights on the grounds that they are unwilling to be dismissed.

According to this most recent report of the International Confederation of Trade Unions, there are numerous obstacles in $\mathrm{BiH}$ regarding the efficient enjoyment of the right to organise. It is especially noticeable in new private companies, especially in multinational retail companies where various kinds of pressures and intimidation of workers exist. Despite the legal ban, workers may in practice often face violations of 
the right to sick leave or to maternity leave, or when an employer dismisses a worker in such conditions. Workers often do not have adequate judicial protection due to a backlog of court cases and delays in the enforcement of judgments.

The report also relates to the dismissal of workers due to their membership of the Metal Industry and Mining Trade Union of Republika Srpska, to the suspension of the President of the Union of Train Drivers of the Federation of $\mathrm{BiH}$, about the problems of the right to strike, etc. There are also other reports that point to difficulties in the area of trade union organisation in Bosnia and Herzegovina. ${ }^{16}$

Regarding legislative provisions on the right to form trade unions, the right to collective bargaining and the right to strike, these are regulated by a number of laws and bylaws, such as the labour laws, public administration laws, strike laws, economic and social council laws, regulations on the registration of trade unions in the court register, etc. These have been enacted at various levels according to the constitutional division of legislative power.

Speaking of international agreements, the specific position of Bosnia and Herzegovina should primarily be pointed out, bearing in mind that it incorporated the European Convention on Human Rights in its legal system via the Constitution of $\mathrm{BiH}$ (Annex IV of the Dayton Agreement) in 1995 and has ratified the Convention as an international agreement. The Constitution provided that the European Convention has priority regarding any law, which puts it in the forefront of constitutional instruments of human rights protection. Apart from the Convention, $\mathrm{BiH}$ has ratified the Conventions of the International Labour Organisation, ${ }^{17}$ as well as the European Social Charter.

However, regardless of the good normative national and international background, there are numerous problems that may be solved in the process of getting on the road to European integration. Directives in that sense are clearly visible in the work of the ETUC, through the obligation of maintaining good social dialogue on tripartite grounds. It is expected that the social dialogue will continue undisturbed and free, in order for the workers' voice also to be undisturbed and visible.

On its road to the European Union, BiH must take into consideration the directives and instructions of the ETUC with the aim of establishing an uninterrupted social dialogue. This refers to a number of rights that are connected with freedom of association, starting from the individual right of workers to become members of trade unions, to the right of trade unions as collective organisations to play an equal role in the public sphere. All three sides in tripartite bargaining are expected to be active, that the trade unions are able to act freely, that associations of employers do not disturb workers' rights, and that the state as an active factor works on connecting these two sets of organisations.

16 For example, see the material in Trade Union Organizing: Precondition for Dignified Labour in Bosnia and Herzegovina Briefing 36, STBIH, Olof Palme International Centre, Solidar, October 2011.

17 No. 87 regarding freedom of association; No. 98 on the right to organise and to collective bargaining; No. 135 on the protection of trade union representatives; and priority Convention No. 144 on tripartite consultation. 
The right to form trade unions and collective rights of workers to act freely and without interruption of their work is the responsibility of trade unions themselves, but primarily it is the responsibility of the government, as the strongest subject, to enact the heteronomous regulations which concern industrial relations. The institutions of executive power competent for labour relations, in a state which is a signatory to the Stabilisation and Association Agreement, are obliged to respect the practice and activities of the European Union and the ETUC, as well as the legal aspects of the right to association that fall within the European Convention on Human Rights and to implement the judgments of the European Court of Human Rights.

The implementation of international understandings of human rights and the abidance of the duties that stem from these, as well as both referring to and applying knowledge in the area of trade unions, is taking a transitional state towards the status of an equal European partner where the independent work of trade unions may be a mirror for a liberated overall social dialogue.

In democratic society, tripartite dialogue is confirmed as a certain way of the peaceful resolution of social and industrial conflicts. It has an important role in the preparation of laws and in issuing important decisions in the labour and social policy sphere. The social dialogue gradually increases to a tripartite one, with three equal sides in the social bargaining activities of tripartite bodies. The institutions of government formulate their active role in the development of social dialogue, which is especially crucial for economic and social problems.

\section{The situation in Republika Srpska}

Examples of a realised tripartite system and an active participation of trade unions in Republika Srpska are the Economic and Social Council and the General Collective Agreement. ${ }^{18}$

In accordance with European practice and duties under international agreements, the composition, jurisdiction, mode of action, financing and other issues that are significant for the work of the Council have been regulated by laws in 2000, especially by the Labour Law ${ }^{19}$ and, later, by the Law on the Economic and Social Council. ${ }^{20}$ The Economic and Social Council supports the development of collective bargaining and brings together the interests of workers, employers and the governing institutions. The Council produces directives on issues such as the improvement of collective bargaining; the influence of economic policy and measures for its implementation as regards social development and the stability of employment policy; wages and prices; health and social protection and security; etc.

The General Collective Agreement, in the part relating to conditions for the operation of trade unions, contains regulations that protect the organisation and freedom of action of trade unions, as well as the duties of employers which are: to enable trade unions to act in accordance with their role and tasks, statute, programme and the international labour conventions; to provide trade unions with conditions for their oper- 
ation, including compensation for salary, to a certain extent, for the president or chair of the trade union; and compensation for professionals carrying out the function of a president in organisations amounting to over five hundred employees.

There is protection for a trade union representative acting legally, i.e. it is not possible to place him/her in another job or with another employer without the consent of the trade union, or to decrease his/her salary; nor to bring disciplinary or pecuniary proceedings against him/her in respect of his/her trade union activities; nor otherwise put him/her in an unfavourable position; etc. The agreement also contains a clause that the employer is obliged to provide for the facility to deduct the union membership fee from workers' salaries, in accordance with the signed authorisation of the worker.

Apart from the protection of the rights of trade unions, the employer must inform workers and their representatives on their rights, duties and responsibilities; salaries; working conditions; the framework for the protection of workers' rights; the general position of the employer and plans for future development; the future of jobs; etc. Trade unions may request from employers other information that may be significant to any right of workers, except as regards information that is considered by the employer to be confidential.

\section{Conclusion}

A transitional state is in a special test of readiness concerning independent trade union organisations, as regards showing that it may incorporate normative segments of the law in its legal system, as well as that it is sufficiently developed as to provide for the implementation of those elements in practice. Therefore, the activities of the ETUC are useful, bearing in mind its directives and guidelines for effective social dialogue in European states.

The freer the right to form trade unions, the higher is the level of social dialogue in a transitional state.

\section{References}

Colgan, F and S. Ledwith (2002) Gender, Diversity and Trade Unions: International Perspectives Routledge.

Harcourt, M and G. Wood (2006) Trade Unions And Democracy: Strategies And Perspectives Transaction Publishers: New Brunswick, New Jersey.

ITUC (2012) Trade union rights violations around the world in 2011 available at: http:// survey.ituc-csi.org/.

Jacobi, O, B. Jessop, H. Kastendiek and M. Regini (1996) Economic Crisis, Trade Unions and the State Biddles Ltd, Guildford and Kings Lynn.

Trebilcock, A (1994) Towards Social Dialogue: Tripartite Co-operation in National Economic and Social Policy-Making International Labour Organisation.

Trade Union Organizing: Precondition for Dignified Labour in Bosnia and Herzegovina Briefing 36, STBIH, Olof Palme International Centre, Solidar, October 2011. 
Commission of the European Communities (1994) 'Preface' to European Social Policy: A Way Forward for the Union a White Paper, COM(94)333 final, Brussels, 27 July 1994.

Council of Europe Social Charter.

European Convention for the Protection of Human Rights and Fundamental Freedoms.

European Trade Union Confederation (2012) A Social Compact for Europe ETUC resolution http://www.etuc.org/IMG/pdf/EN-A-social-compact-for-Europe.pdf

Treaty on Functioning of the European Union.

Consolidated text of the Treaty on the European Union. 